\title{
Investigation On Human Trafficking Especially Women
}

\section{Vinorika Padmadayani *) and Lathifah Hanim**)}

*Student of Master of Law, Faculty of Law, Sultan Agung Islamic University Semarang, email: vinorika9311@gmail.com

${ }^{* *}$ ) Faculty of Law Universitas Islam Sultan Agung

\begin{abstract}
This study aims to identify and analyze the implementation of investigations the criminal act of human trafficking, especially women at the Brebes Police, what affects the rampant of human trafficking human trafficking, the factors that hinder and solutions in the implementation of the investigation of human trafficking, especially women in Brebes Police. This research uses an empirical juridical approach with descriptive analysis research specifications. The data used are primary data and secondary data obtained through interviews and literature study. The data analysis method used was qualitative analysis. Furthermore, based on the research results it can be concluded; The investigation of the criminal act of human trafficking is in accordance with the Criminal Code, but the investigators of the PPA Unit at the Brebes Police found a problem, namely that the laws and policies regarding human trafficking have not been properly socialized. The poverty factor, the desire to get rich quick, and the habitual factors of the population that become a culture, Keywords: Investigation, Crime, Human trafficking, women.
\end{abstract}

\section{Introduction}

Indonesia is a vast archipelagic country with a large population. This advantage is one of the main obstacles to creating equitable development in all areas of community life. In general, it can be seen that the low level of education of women is one of the factors causing the rampant crime of trafficking. The low level of education and limited knowledge of women about their rights are often used by trafficking networks to trick victims into looking for work.

Another thing that is often experienced by women who are victims of trafficking is unfair treatment from their employers in the form of acts of violence both physically and mentally, even they often do not get a decent wage according to their rights. What is even more concerning is that they do not know where they can seek protection, and they often do not even realize that they have become victims of trafficking crimes committed by neat and organized syndicates. Therefore, quite a number of victims of trafficking choose to survive with the consideration of the urgent needs of life and the difficulty of finding other better types of work with their low educational background.

When viewed juridicaly, the criminal act of trafficking in women violates human rights and is contrary to the provisions of the applicable laws. This is in accordance with Article 27 paragraph (2) which states that "every citizen has the right to work and livelihoods worthy of humanity. ${ }^{1}$ In addition, the criminal act of

${ }^{1}$ Constitution Republic of Indonesia 1945 
trafficking in women and children also violates the provisions of Article 297 of the Criminal Code, Act No. 26 of 2000 concerning Human Rights Courts. In addition, the rules regarding the criminal act of trafficking which have been ratified in Act No. 21 of 2007 concerning the Eradication of the Crime of Human trafficking.

In the Chief of Police Regulation Number 14 of 2012 concerning management of criminal investigation, Article 15 states that the stages of investigation begin with investigation, sending of Notification Letter on the Commencement of Investigation (SPDP), coercion, examination, case title, settlement of case files, submission of case files. To the public prosecutor, submitting the suspect and evidence, and terminating the investigation. ${ }^{2}$

The Ministry of Women and Children Empowerment and the Brebes Regency Government have tried to prevent human trafficking in Brebes by forming a community that cares about the crime of human trafficking (TPPO). Given that Brebes Regency is one of the most vulnerable areas because many of its residents work abroad or outside the city. Even Brebes Regency is one of the biggest suppliers of such labor. "So there is a potential for criminal acts of human trafficking. An example of the cases he has handled, Rini said, most of the victims came from the lure of working abroad with a very large salary. So that many residents are deceived and are willing to leave their hometowns,"said Head of PPA DP3KB Brebes, Rini Pujiastuti. ${ }^{3}$

Trafficking is the illegal trafficking of humans for commercial purposes of sexual exploitation or forced labor. This term comes from English and means "illegal trade" or illegal trade. This is a modern form of slavery ${ }^{4}$ Human trafficking does not occur automatically, but there are factors behind the occurrence of cases of trafficking against women and children, including poverty, low education, promiscuity, and lack of information. ${ }^{5}$

\section{Research Methods}

The approach method used is juridical empirical, a way to solve research problems by examining secondary data first and then continuing research on primary data in the field. Research Specifications: descriptive analysis, focusing on the problem and then processed and analyzed to draw conclusions. ${ }^{6 .}$ Types and sources of data consist of primary and secondary data, while data sources were obtained through interviews and literature study.

\footnotetext{
2 Tolib Efendi, Dasar-Dasar Hukum Acara Pidana; Perkembangan Dan Pembaharuanya di Indonesia, Malang : Setara Press, 2014, p.69

3 https://www.kompasiana.com/amp/kuntorosip/5c07563cc112fe494028cbb3/kemen-ppabentuk-komunitas-tppo-di-brebes, Downloaded on Wednesday, June 17, 2020

${ }^{4}$ Cahya Wulandari, Tindak pidana Perdagangan Orang (Human Trafficking) Khususnya Terhadap Perempuan dan Anak: Suatu Permasalahan dan Penanganannya di Kota Semarang, Edition 9 September-December 2014

${ }^{5}$ Lathifah Hanim, Perlindungan Hukum Terhadap Korban Kejahatan Perdagangan Orang (Studi

Tentang Implementasi Undang-Undang No 21 Tahun 2007), Jurnal Pembaharuan Hukum Vol 2. No 2. Mei-Agustus 2015 http://jurnal.unissula.ac.id/index.php/PH/article/view/1434

${ }^{6}$ Saifuddin Azwar, Metode Penelitian, Pustaka Pelajar, Yogyakarta, 2014, p. 7
} 
Data collection methods are primary data obtained through interviews with sources and secondary data through relevant literature studies, either in the form of theories or opinions from experts. Documented in the literature. The data analysis method used is qualitative analysis, namely by describing the data in the form of regular, logical and effective sentences.

\section{Results And Discussion}

\subsection{Implementation Investigation of the Crime of Human Trafficking, Especially Women in Brebes Police}

The investigation into the criminal act of human trafficking, especially women and children, was carried out by the Women and Children Service Unit (PPA Unit) because in this crime the victim was a woman. As for the stages of the process of carrying out an investigation into the criminal act of human trafficking by the PPA Unit of the Brebes Resort Police, namely:
a. Police Report Making
b. Inspection and Filing Process
c. Suspect Examination
d. Witness Examination
e. Examination of Victims or Reporters
f. Evidence Inspection
g. Case File Filing
h. Submission of Case Files

\subsection{Which Affects the Rise of Crime of Human Trafficking, especially Women in Brebes Police}

In general, women are vulnerable to becoming victims of trafficking and exploitation. Those who become victims are mostly from vulnerable groups of society. In accordance with the results of the research that the author can by conducting interviews with investigators of the PPA Brebes Police Unit, the factors that cause trafficking of women in the jurisdiction of the Brebes Police are as follows:

a. Lack of awareness and wrong concept of thinking in society,

b. The poverty factors that force many families to plan their life support strategies include working due to debt bondage, the desire to get rich quick, and the cultural habits of the population.

c. The desire to work instantaneously even with minimal skills.

d. Lack of employment 9

To overcome this, efforts should be made to protect women trafficking victims but there are many challenges, so awareness and participation of all communities, state administrators and law enforcement officials is needed.

So far, the problem of trafficking and exploitation of women has only focused on problems that have occurred and the resolution of cases. Meanwhile, efforts to prevent and fulfill women's rights are still lacking. Community participation is needed, both institutionally and individually. This can be started 
with parents, teachers, religious leaders, community leaders, and government officials. It must be done together to make the parties aware of the potential for the crime of human trafficking, especially women and children in the jurisdiction of the Brebes Police.

\subsection{Obstructing factors and solutions in the investigation of human trafficking, especially women in Brebes Police}

Obstacles encountered by investigators of the PPA Unit at the Brebes Resort Police in carrying out investigations into criminal acts of human trafficking, especially women at the Brebes Resort Police, are as follows:

a. Cost; The available operational costs are inadequate, because the costs incurred for the investigation process are quite large. Once in carrying out the process of investigating costs with the articles of association received by the investigator PPA Unit Brebes Police in carrying out a smaller investigation process that is usually issued by the PPA unit Brebes Resort Police.

b. Personnel; The Brebes Resort Police provides a Women and Child Protection Unit (PPA) which is handled by the Female Police. The PPA Unit of the Brebes Resort Police is very important in providing services for cases related to trafficking of women. However, the number of female police on duty in the PPA Unit of the Brebes Resort Police is very small, only two members, is very lacking, considering that the problems handled are very diverse, of course not only cases of human trafficking but other criminal cases related to women and children in the jurisdiction of the Police of Brebes.

From the facts above, it can be seen that the number of personnel determines the course of the investigation process. If the number of personnel does not match the number of cases that have been submitted, it will cause a delay in the process of investigating criminal cases of human trafficking in the jurisdiction of the Brebes Resort Police.

c. Facilities and infrastructure; Facilities and infrastructure are one of the factors that greatly support whether or not an investigation process can proceed in accordance with existing regulations. Based on interviews conducted by the author with investigators from the PPA Unit of the Brebes Resort Police who handled cases of criminal human trafficking, investigators admitted that the existing facilities and infrastructure are currently inadequate, making it difficult to carry out the investigation process. Investigators must examine an expert witness, namely the BP3TKI Institute in Semarang. Due to the long distance, it is difficult for investigators to carry out investigations, but this is still done to resolve the case.

d. Public legal awareness factor; Public legal awareness also influences the implementation of the role of the police. Often people do not understand what and how constitutes the criminal act of human trafficking, so that the role of the community is still weak in law enforcement efforts against the crime of human trafficking as a result, no community reports the criminal act of human trafficking to the police, especially in the jurisdiction of the Brebes Resort Police. . 
The efforts / solutions found by investigators in overcoming obstacles faced by investigators in the process of investigating criminal cases of human trafficking in the PPA Unit in the jurisdiction of the Brebes Police are as follows:

a. In terms of cost; As one of the supporting factors for conducting an investigation, the efforts made are by adding costs. Based on the results of interviews with Brebes Police investigators, the fees obtained were from the PPA Section Officer, which then the PPA Section Officer proposed an additional budget for the following year to be submitted to the Brebes Police.

b. In terms of personnel; There needs to be additional personnel in monitoring every case development, especially those related to the Crime of Human trafficking in the jurisdiction of the Brebes Resort Police so that they do not burden the officers in the PPA Unit of the Brebes Resort Police with other tasks that are not related to the problem of criminal cases that occur with women. and Children, especially the Crime of Human Trafficking, so that officers in the PPA Unit of the Brebes Resort Police can focus more on handling every case of the Crime of Human trafficking that occurs in the jurisdiction of the Brebes Resort Police.

c. In terms of facilities and infrastructure; The effort made by the police apparatus in overcoming obstacles in the infrastructure was to continue to carry out examinations of expert witnesses even though it was a long distance to resolve the case.

d. Community Factors; The investigators of the PPA Unit at the Brebes Resort Police in overcoming obstacles from the community made efforts by approaching the local community. The investigators of the PPA Unit at the Brebes Resort Police also provided socialization to the public about the Crime of Human trafficking. In approaching the community, the police also collaborate with the Brebes District Manpower Office.

\section{Closing}

\subsection{Conclusion}

a. Investigation of the criminal act of human trafficking is in accordance with the Criminal Code. However, investigators from the PPA Unit of the Brebes Resort Police found a problem, namely that the law and policies regarding human trafficking had not been properly socialized to the public.

b. The factors that cause trafficking of women in the jurisdiction of the Brebes Police are as follows: Lack of awareness and wrong concept of thinking in society; The poverty factor forces many families to plan their life support strategies so that they are attracted to work abroad due to debt bondage, the desire to get rich quick, and the cultural habits of the population; The lack of jobs in Indonesia has attracted some people to work abroad.

c. The obstacles experienced by investigators in carrying out the investigation process are the lack of personnel or investigators in carrying out investigations, the lack of infrastructure in carrying out investigations and also the lack of costs given to investigators during the investigation process, and victims of criminal acts who are still afraid to report their cases. To the police 
because of threats from the perpetrators of the crime and factors from the public who do not know the impact of the criminal act of human trafficking.

Efforts made against the obstacles faced by PPA Unit investigators in handling cases of criminal human trafficking are by increasing the number of investigators so as to ease the burden on other investigators, complete the infrastructure that will be used both in the investigation and in the investigation process and also increase operational costs during ongoing investigation process conducted by investigators. In addition, investigators also provide advice and counsel to the public regarding the crime of human trafficking.

\subsection{Suggestion}

Investigators in the PPA Unit must be more serious in handling women's cases, especially the criminal act of human trafficking so that the investigation process runs smoothly and quickly finishes; Investigators must also understand more about the regulations on human trafficking, especially women and children, so that in the implementation process there are no more obstacles; Investigators must also pay more attention to internal problems that become obstacles to investigating the criminal act of human trafficking, especially women.

\section{References}

\section{Books:}

Tolib Efendi, Dasar-Dasar Hukum Acara Pidana; Perkembangan Dan Pembaharuanya di Indonesia, Malang: Setara Press, 2014

Cahya Wulandari, Tindak pidana Perdagangan Orang (Human Trafficking) Khususnya Terhadap Perempuan dan Anak: Suatu Permasalahan dan Penanganannya di Kota Semarang, Edition 9 September-December 2014

Saifuddin Azwar, Metode Penelitian, Pustaka Pelajar, Yogyakarta, 2014

\section{Regulations:}

Constitution Republic of Indonesia 1945

Act No. 2 of 2002 concerning the Police of the Republic of Indonesia

Act No. 26 of 2000 concerning Human Rights Courts

Act No. 21 of 2007 concerning the Eradication of the Crime of Human Trafficking

\section{Internet:}

https://www.kompasiana.com/amp/kuntorosip/5c07563cc112fe494028cbb3/ke men-ppa-bentuk-komunitas-tppo-di-brebes, Downloaded on Wednesday, June 17, 2020

Lathifah Hanim, Perlindungan Hukum Terhadap Korban Kejahatan Perdagangan Orang (Studi Tentang Implementasi Undang-Undang No 21 Tahun 2007), Jurnal Pembaharuan Hukum Vol 2. No 2. Mei-Agustus 2015 http://jurnal.unissula.ac.id/index.php/PH/article/view/1434 